\title{
MAINSTREAMING GENDER IN PURSUIT OF MILLENNIUM DEVELOPMENT GOALS IN WATER RESOURCE GOVERNANCE IN BUHERA, ZIMBABWE
}

\author{
Ephraim Chifamba, Researcher \\ Great Zimbabwe University, Masvingo, Zimbabwe \\ E-mail: ephchifamba00@gmail.com
}

\begin{abstract}
Women have the primary role for the management of household water supply, sanitation and health. Water is necessary for drinking, but also for food production and preparation, personal hygiene, care of the sick, cleaning, washing and waste disposal. Because of their dependence on water resources, women have accumulated considerable knowledge about water resources, including location, quality and storage methods. However, efforts geared towards improving the management of the finite water resources and extending access to safe drinking water and adequate sanitation, have often overlooked the central role that women play in water management. The study used both qualitative and quantitative research methodologies. The research noted that despite increased gender awareness and the availability of much more information on women's and men's roles in water management, gender is not yet mainstreamed into this sector. The study revealed that prospects for effective gender mainstreaming in water resource management will hinge on how the main agenda can address the transformation of gender relations and treat water as a human right so as to realize the Millennium Development Goals (MDGs) in Buhera. A gender equity approach within the water sector, should strive for a more balanced division between women and men in access to information, sharing of contribution, the degree of decision making, access to resources and benefits and the control over water resources. Addressing women's concerns and mainstreaming gender in water governance through a livelihood approach is critical because this generates an understanding of people's livelihood strategies and their decision making mechanisms and processes. Significant support and capacity development are required to enhance the participation in decision making processes for the success of water management initiatives.
\end{abstract}

\section{KEY WORDS}

Millennium Development Goals; Mainstreaming Gender; Water and Sanitation; Participation; Decision Making; Zimbabwe.

Throughout the world, women bear disadvantages with several social factors imposed on them by religion and culture (Agarwal, 1997). These disadvantages and differences vary from country to country and region to region, but nevertheless, it has been proven that women and girls in poor economies, in particular in rural areas, experience a colossal gender disproportion across societies (Blank and others, 2002). Layers of disparity for women in all socio-economic levels result in a lack of opportunities to access education, health, income and political influence. The Millennium Declaration endorsed by the world's governments in September 2000 recognized the importance of gender equality and mainstreaming to be the most efficient methodology and tool to meet the needs of the goals and produce a sustainable end result. Several water development projects have confirmed that gender mainstreaming in water resources management will have an enormous effect in sustainable development and poverty reduction

The past few decades have seen a changing prominence on the role of women and gender relations in water resource management (Gleick, 2006). This has been necessitated by the widespread recognition that the world is facing a growing water crisis, affecting the well being of millions of the poorest people. Rapidly growing populations, urbanization, agricultural intensification and climate change all contribute to greater competition and scarcity of water resources (Cleaver, 1998). Despite increased provision of water sources over the past few decades and the development of low - cost, sustainable technical solutions to many aspects of water provision, millions still suffer from water-related diseases and the 
physical, social and economic burden associated with scarcity (Diamond, 1997). A number of international initiatives including the MDGs aim to tackle this global predicament through improving the governance of water and setting goals for the provision of supplies to increased numbers of people within the framework of poverty alleviation and environmental sustainability. The greater participation of women and the espousal of gender responsive approaches are progressively seen as fundamental to the accomplishment of MDGs (Cornish and others, 1999; ACC/ISGWR, 1992).

Notwithstanding the reality that water is critical to the livelihoods and well being of poor communities in Buhera, thousands of poor households suffer from lack of access to fresh water, inadequate water for food production and the effects of environmental change. Increasingly, enhanced water supply management is seen as centrally important to poverty alleviation and to safeguarding a sustainable future for thousands of people with vulnerable livelihoods in the marginal environment of Buhera. The impact of inequitable access and poor management is huge. The United Nations Development Programme Report (UNDP) (2010) indicated that over 500000 people in the district lack access to improved drinking water, and 240000 people lack sanitation. As a result the burden of death and diseases related to inadequate water is high, with an estimated mortality of 120 people a year, and millions more suffering water related diseases (UNDP, 2010). The majority of those affected are likely to be children under five years old, affected by diarrhea disease. The MDGs have set a road map for nations to make appropriate measurements to eradicate poverty and hunger, provide secondary education, promote gender equality and empower women, reduce child mortality, improve maternal health, combat HIVIAIDS, ensure environmental sustainability and develop global partnership in order to contribute to economic development. It is the acquiescence of this paper that water should be treated as an economic, social, and environmental good; water policies should center on the management of water and not just the provision of water; and that women should play a fundamental role in the provision, management and conservation of water to achieved MDGs.

\section{GENDER MAINSTREAMING AND SUSTAINABLE WATER DEVELOPMENT}

Gender mainstreaming is defined as the process of assessing the implications for women and men of any planned action, including legislation, policies or programmes, in any area and at all levels (Brundlandt, 1987). It is a strategy for making the concerns and experiences of women as well as men an integral part of the design, implementation and monitoring and evaluation of policies and programmes in political, economic and societal spheres, so that both women and men benefit equally. The major objective of addressing gender disproportion is to achieve gender equality in water resource management.

Gender mainstreaming has been an endeavor to incorporate a gender approach into water management efforts. In practice, gender mainstreaming means being conscious in giving visibility and support to both men and women's contributions, rather than assuming that both groups will benefit equally from gender neutral development interventions (Postel, 1992). The objectives of mainstreaming gender issues in water resources management endeavors to:

- Reduce gender inequalities that may exist in water resource management;

- Encourage both men and women to jointly participate in finding solutions to their problems; ensure that their specific needs are satisfied and that they benefit from joint participation for positive impact on their lives;

- Create the conditions for men and women to have equal access to water resources and benefits;

- Create the conditions for equal participation in planning, implementation and decision making of identified joint endeavors and actions.

Policies and programmes that disregard the differential impact on gender groups are often gender blind and potentially harmful for human sustainable development. Within the water sector, gender mainstreaming includes identifying gaps in equality through the use of sex - disaggregated data, developing strategies and policies to close the gender gaps, 
devoting water resources and expertise for implementing such strategies, monitoring the results of implementation, and holding institution accountable for outcomes that promote gender equality (Espego, 1993).

Gender mainstreaming does not necessarily mean that women and men will become the same, but rather implies equal treatment of women and men in laws and policies, and equal access to water resource within families, and communities. In order to achieve sustainable development, a two prolonged approach in water resource governance is required. Firstly, there is need for systematic analysis and addressing specific needs of both men and women. Secondly, interventions should permit both men and women to participate in, and benefit equally from development efforts. A comprehensive understanding of gender roles within the community, and consideration of women's and men's specific interests, needs, and priorities is necessary to realize and sustain the MDGs (Brown and Nooter, 1992). Gender mainstreaming is not solely a women's issue, but it seeks to address water management issues to the benefit of both men and women. Gender parity should serve to the advantage of both men and women and cannot be achieved without full engagement and participation of both sexes (Cleaver and Elson, 1995).

In water resources management, an uncoordinated and sectoral approach has resulted in water depletion and environmental degradation from overexploitation of water resources, inappropriate allocations among competing uses, inequitable distribution of benefits and burdens, and inadequate operation and maintenance of infrastructure (Bhatia and others, 1993). Inadequate involvement of both men and women has hindered programmes and projects aimed at addressing sustainability in water resources management. The reality is that a community is not collection of homogenous people living in a particular geographic area. It is made up of individuals who command different levels of power, wealth, influence and ability to express their needs, concerns and rights. For the success of water management initiatives, people's strategic needs should be addressed.

Most communities contain competing interest groups. Where water resource is scarce, there is competition for supplies and those at the lowest end of the power spectrum, (the poor women and children) will go without water (Cornish and others, 1999). Unequal power relations place women and children in a disadvantaged position. Gender mainstreaming helps water sector agencies allocate water resource better to meet the needs of different groups. People centered paradigms do not necessarily ensure that gender perspectives are taken into account. Thus, a deliberate gender mainstreaming approach is required to ensure that both men and women are part of water project planning, implementation and evaluation. In water resources management, gender mainstreaming is necessary in bringing both institutional and organizational change necessary to ensure gender equality (Meinzen-Dick and Rosegrant, 1997).

Without specific attention to gender issues and initiatives, water development initiatives can reinforce gender inequality between men and women and even increase gender disparities and discrimination. Projects need to enable both men and women to benefit equally from water initiatives. Water management initiatives can also result in reinforcing existing inequalities, even when there may be opportunities to help support people's efforts to build more equitable communities.

International Policy in Water Governance and Poverty Alleviation. The importance of evolving both men and women in the management of water and access related questions has been recognized at the global level starting from the 1977 United Nations Conference at Mar del Plata, the International Drinking Water and the Environment in Dublin (January, 1992), which recognized the central role of women in the provision, management and safeguarding of water (Gleick, 2006). Reference is also made to the involvement of women in water management in Agenda 21 and the Johannesburg Plan of Implementation. Furthermore the resolution establishing the international Decade of Action, 'Water for Life' calls for women participation and involvement in water-related development efforts and it coincides with the timeframe for meeting the Millennium Development Goals (Cornish and others, 1999). The following conventions emphasized the importance of involving women in water resource management. 
New Delhi. In the New Delhi document no mention is made of gender, but women are mentioned several times. In relation to water management, the New Delhi document call attention to the situation that while the household is the level at which improved water supply and sanitation are aimed, projects and programmes frequently have the community as their lowest level of analysis and work. As part of water resources management the New Delhi calls attention to the household level and to the roles of women, but only in a domestic capacity, as managers of the domestic water collection and waste disposal and as educators of the children. Women's indigenous public roles remain unmentioned, as also are the responsibilities of men and the male-female relationships which co-determine water and waste management. The document recognizes that too little is known about water management within the household and responsibility of women in water governance. Very little are known about the daily lives of women, how they make choices, and what influences them (Bosrup, 1990).

Dublin and Rio de Janeiro. The singling out of women's responsibilities in water resources management without paying consideration to the roles of males and the interlinkages and balance between male and female rights, responsibilities and opportunities, is also evident in the reports from Dublin and Rio de Janeiro. The Dublin statement mentions the central role of women in the provision, supervision and safeguarding of water. It calls for the critical role of women as providers and users of water and custodians of the living environment to be reflected in institutional arrangements for the development and management of water resources (Cornish and others, 1999).

The Dublin and the Rio Summits further stresses the multi-sector interest in the utilization of water resources and the mutual impacts that action in one sector can have on water availability, use and quality in other sectors. The Dublin and the Rio summits contain seven programme areas for action in the 21st century namely integrated water resources development and management; water resources assessment, or the collection of data needed for better integrated water resources development and management; the protection of water resources; water quality and aquatic ecosystems; the supply of drinking water and sanitation; water for sustainable rural and urban development; water for sustainable food production and rural development and the impacts of climatic change on water resources. Women feature in four of the seven programme areas namely integrated water resources development and management; drinking water supply and sanitation; urban development and food production and rural development. They are mentioned in relation to water resources assessment, water quality protection and climatic change. More and better data collection systems, more research and development programmes and better institutional frameworks are recommended to better forecast and manage droughts and floods and enable better integrated management and development of water resources (Brown and Nooter, 1992).

Noordwijk and Paris. The Noordwijk conference and the OECD/DAC meetings which followed the Dublin and Rio conferences on water and water resources management also stress the more equitable involvement of women in decision making, management bodies and training. The Noordwijk political statement and action plan declares that water management programmes need to be based on partnerships involving all stakeholders (users - especially women, community associations, regional and central government, public and private sector agencies, non-governmental organizations) (Blank and others, 2002). In the action plan the participating governments pledged to improve partnership and participation and therefore involve local communities, user organizations, women and nongovernmental organizations in the planning of, and decision-making procedures about those systems. They also recommended the developing plans to build up the capacity of all stakeholders, including empowerment of communities, in particular the women, through proper training and education at community level (Danish Agency for Development Assistance, 1999).

Most of the statement of the Noordwijk conference gives the undifferentiated community or household as the lowest level of water resources development and management, and singles out women's shares in isolation from the contributions and 
responsibilities of men and changes in male-female relations (Bhatia and others, 1999). But two statements recognize that communities and households do not have homogenous sets of interests, needs and knowledge. Consequently, different interest groups in terms of age, sex and socio-economic status must be identified and given a proper say in local decisions and management. The Noordwijk and the Paris meetings gave special emphasis to creation of partnerships among all stakeholders in order to address different needs of women, and youth and involve all sections of society in resolving problems that affect them (Shiva, 1996).

The involvement of all stakeholders in policy formulation and the growth of proficient and accountable sector organizations was one of the five principles for the new policy agreement on water resources identified by the OECD/DAC conference in Paris. A unified and cross-sector approach in the development and management of water resources requires that all stakeholders are involved and that the differences in roles, needs and rights are to be generally understood. Stakeholders do not only include the higher and lower level institutions, but also other institutions such as government and non-governmental organizations. Water governance at the global level has seen a changing emphasis on the role of women and gender relations. In the 1980s' policies and interventions adopted a welfare approach, viewing women and children as the primary recipients and beneficiaries of improved water provision (Bhatia and other, 1993). However, since the 1990s', a new policy consensus on water and sanitation was formulated at a number of international conferences. In most recent international policy statements and initiatives, a focus on women has been seen as a crucial to improving the management of governance of water within an overall context of poverty alleviation (Postel, 1992).

Second World Water Forum, 2000. The conference noted that in addition to being prime users of domestic water, women use water in their key role of food production and that women and children are most vulnerable to water related disasters. The forum concluded that women's involvement in water and sanitation would increase water governance. Since women bear the brunt of the burden of poor management, they can be capacitated and empowered through greater and more effective participation.

Conferences on Fresh Water, 2001. At the Fresh water, Conference in Bonn, the policy statement emphasized the need for a gendered approach involving both men and women, while also suggesting that in order to achieve this; women's roles in water-related areas require strengthening (UNDP, 2010). Further emphasis on equality was given in the statement of the Third World Tyoto Water forum in 2003. In the quest for achieving MDGs, many governments face the crisis of governance and need an integrated and gender sensitive water resources management approaches that address core ecological and human needs. The Ministerial Declaration stated that in managing water states should ensure good governance with a stronger focus on household and neighborhood community based approaches by addressing equity in sharing benefits, with due regard to pro-poor and gender perspectives in water policies (Gleick, 2006).

Millennium Summit, 2000. Global meetings and policy statements have been concerned with a broad spectrum of goals from poverty eradication to environmental sustainability. The MDGs adopted at the Millennium Summit at the United Nations in New York in 2000 emphasized goals on the support of gender equality and empower women and to ensure environmental sustainability (Cleaver and Elson, 1995). One of the fundamental targets for the goal on ensuring environmental sustainability is to halve by 2015 the proportion of people without access to safe drinking water and basic sanitation. At the Johannesburg Summit on Sustainable Development commitments were made to promote women's empowerment and emancipation and incorporate gender equality in all the activities specified in Agenda 21, the Millennium Development Goals and the Plan of Implementation of the Summit (Gleick, 2006). Since the Millennium Summit, it has become increasingly recognized that women should play an imperative role in water management and that this responsibility can be improved through the approach of gender mainstreaming. In water and sanitation, gender mainstreaming is justified for reasons for efficiency and effectiveness; a gender sensitive approach helps to ensure that supplies are provided and managed more 
sustainably. Gender mainstreaming helps to empower women and so furthers broader goals of parity within society, contributing to poverty alleviation and social exclusion.

Water Management in the Context of Complex Livelihoods. There are a number of factors that shape both gender relations and the access to water resources. The kinds of question which should be noted while considering water and sanitation from a gender perspective include:

- How men and women use water resources and for what purpose;

- How contributions to water supply improvements (labor, time, payments) are divided between men and women, rich and poor;

- Who makes decision about water and sanitation;

- Do men and women bear the benefits and cost of managing water and sanitation equitably.

From the questions raised above, it can be noted that adopting a gender -sensitive approach in water resource governance requires a holistic analysis of water resources and relationships and the contexts within which people live their lives. For the past decades the water sector has been divided into those concerned with domestic water supply (water for drinking, washing and maintenance of hygiene); productive water (mostly water used in agriculture) and the environmental water sector (concerned with flood coping mechanisms and drought mitigation) (Cornish and others, 1999). Despite the acceptance of the need for integrated water management, many interventions have remained sub-sectoral in focus. Irrigation planners are still concerned with crop production, just as health planners are focus on the quality and quantity of water used in the household as a productive unit. This approach inadequately reflects the ways in which people organize their lives.

Rural livelihoods comprise multifaceted and interconnected processes, often shaped by gender and other social relations (FAO, 1998). For instance, women may consider the irrigation canal an appropriate place for washing clothes or drinking water supply serious for their vegetable gardens and keeping small livestock alive. These meticulous concerns of women are rarely integrated into the planning process. A more robust gender- sensitive water management approach may assist in identifying complementarities between different uses of water resources.

Over the past decade, women have been the focus in the domestic subsector, their pivotal place based primarily on the idea of their natural role as household managers (Jackson, 1998). Women have been identified as the main drawers of water, the primary promoters of hygiene behaviors among children and those most likely to benefit from improved water provision in terms of alleviation of the burden of their domestic tasks. In the 1980s, much of the tasks associated with the International Drinking Water Supply and Sanitation Decade emphasized the water sector as a 'women's sector' based on women's responsibilities and the household division of labour (Hatibu, 2003; Jackson, 1998; Tinker, 1990). Much of the work identified multiple public and private roles for women in the management of domestic water, detailed the convolution of interaction around women's water use and stressed the need for planning within a social context. Nevertheless, the domestic water subsector has been slow in expanding its focus to women's productive concerns and to men's involvement in water resource management.

The past decade has witnessed little emphasis on gender perspectives in the water subsector devoted to water for nature although it is clear that men and women may have different interests in drought mitigation, flood protection forest and fisheries management (Gleick, 2006). In the early 1990s, eco-feminists claimed that women gender-specific interests coincide with water resource conservation and that their instinctive understanding of nature makes them 'natural' water managers (Plumwood, 1992). However, such feministic perspectives are problematic in gender-equality terms, as they mirrors ideas that women are the 'ideal' managers of domestic water and that therefore the burden of responsibility for such management and its outcomes should naturally fall upon them (Green and Baden, 1995). This simplified gender perspective has been replaced by more expressed understanding that men and women do have different priorities regarding natural resources and that these will shape their involvement in water resource management. 
In most developing economies, women have assumed the responsibility for food production and this has disproportionately affected them. Poor rural households depend heavily on common pool resources such as water sources, grazing lands and forests for food, fuel and fodder. Entitlement and access to natural resources are often shaped by gender and other power relations. A more clear gender approach could assist in analyzing how land rights, rights of use and command over labour helps to define inclusion in and exclusion from such resources, particularly in periods of ecological stress and natural disaster. For example, in Haiti people cope with the earthquake by sale of assets (Sing and others, 2000). Thus women are at risk because their assets such as household utensils are devalued in circumstances that command low prices than men's assets such as farm implements and animals.

It is important to note that a gender perspective facilitates looking beyond uses of water and other resources to the societal relations that place people in positions of advantage and disadvantage. The understanding of gender relation in water management should move from the use of gender analysis techniques to beyond identifying women's and men's separate vulnerabilities towards understanding how building on livelihood interdependencies within communities can strengthen their resilience in the face of natural disasters (Shiva, 1989).

Gender mainstreaming is an important aspect of water governance. Gender mainstreaming seeks to ensure that policies, institutions and programmes respond to the needs and interests of women as well as men, and distribute benefits equitably between women and men. Gender is mainstreaming leads to greater fairness, equity and justice for women and men, thus, enhancing the accountability of institutions to achieve the targets of the MDGs. Without attention to gender issues and initiatives, projects can reinforce inequalities between men and women and even increase gender inequalities. In the study area, without addressing these gender disparities, targets such as the Millennium Development Goals relating to water, are unlikely to be achieved unless gender perspectives are integrated into planning and implementation activities.

\section{STATEMENT OF THE PROBLEM}

Although much effort has been directed towards addressing gender inequality in water resource management, a gap still exists between how men and women access and use water resources. Over the past decades gender segregation in the water sector have persisted due to the fact that the attitude of water users and policy makers towards women have not changed to accommodate the strategic needs of women in water resources management. Despite the feminization movement and affirmative action perceptions about women have not changed. The legal framework has attempted to reflect gender needs, but practices at the local level have lagged behind. As a result of poor implementation of existing legal frameworks, women continue to have limited access to water resources for productive purposes and this has enhanced the feminization of poverty. In light of this, it is vital to investigate how gender relations influences access, uses and management of water resources in the quest for the achievement of MDGs.

The aim of the study is to investigate how water management has managed to strategically mainstream gender aspects.

Objective of study - to identify the constraints faced by women in water resources management.

\section{MEASURES, MATERIALS AND METHODS}

Sampling techniques and sample size. One hundred and fifty (150) respondents from a total 1869 people in Buhera were randomly selected from the households in Buhera District. The sample size was limited to 150 by limited financial resources and to maintain validity and reliability the researcher made sure that key informants were interviewed and triangulation methods were used. A non-random technique, judgmental sampling was used to select key 
informants for the research. They were selected by virtue of their involvement in water resource management and use.

Survey questionnaires. This was the mostly used data collection technique. 150 questionnaires were administered on a one to one basis to allow probing. Out of 30 targeted key informants, 26 responded. These were representatives of the department of water resources development, agriculture research and extension services, agriculture research council, Ministry of Water and Rural Development, conservation agencies, traditional leaders and non - governmental organizations.

Focus group discussion. Forty one respondents participated in a focus group discussion. Participants were randomly picked from respondents who were not considered for questionnaire interviews. The researcher led the discussion using a checklist of questions. The responses were noted. The average age of the participants in the focus group discussions was forty. The group comprised of twenty males and fifteen females. The technique allowed truthfulness as the participants' views were openly shared. Structured and semi-structured interviews with key stakeholders were also conducted in the study area.

Preference ranking (proportional piling and pair-wise ranking). The approach was used to assess people's preferences and the importance they attach to gender mainstreaming in water resource management. The researcher also made use of seasonal diagramming to indicate annual variations and different activities taking place during different seasons. The method provided an understanding of the diversity of activities taking place within the water sector.

Secondary data. Secondary data on water management, legal framework, and use were used in this study. The data were mostly obtained from textbooks, journals, papers and magazines. The researcher also used the internet to provide important information on gender mainstreaming in water resource management.

Data Processing. Questionnaires administered in Buhera District were coded 1-150 while for the key informants were coded from 1-30. Data of each questionnaire was processed by a program called Statistical Package for Social Sciences (SPSS). Graphs were drawn using SPSS generated data.

\section{RESULTS OF RESEARCH}

Age-sex. Respondents were drawn from both sexes but females constituted the majority compared to their male counterparts $(70 \%$ as compared to $30 \%)$. The ages of participants ranged slightly below 25 years to 65 years. Data was collected from participants who are economically active and no respondent was in the retirement age group or a minor. The slightly below 25-35 years age group was the largest that constituted $40 \%$ and the 3645 years age group was the second largest constituting $25 \%$. The $46-55$ years age group constituted $23 \%$ and those between the $55-65$ years age group constituted $15 \%$ of the total respondents. Table 1 shows the age-sex composition of respondents.

Table 2 - Age-Sex Composition of respondents

\begin{tabular}{|c|c|c|}
\hline Age group & Males & females \\
\hline Below 25-35 years & 30 & 29 \\
\hline $36-45$ & 10 & 15 \\
\hline $46-55$ & 4 & 16 \\
\hline $56-65$ & 5 & 10 \\
\hline Total & 30 & 70 \\
\hline
\end{tabular}

Source: Survey, 2013.

Academic Qualification of Respondents. Respondents were drawn from varying educational background. It included those who had no formal education, those with elementary education, to holders of tertiary education. Generally the research showed that a number of respondents had acquired formal education, as $86 \%$ of them had acquired either vocational training after primary education or Zimbabwe junior certificate level of education; 
$49 \%$ had attained ordinary level. Only a few had no formal education (14\%) which shows that the majority of respondents could read and write. However, the majority of respondents who were illiterate were females. The research noted that patriarchy has influenced women's educational achievement.

Gender Participation in Decisions, Implementation and Management of Water Initiatives. Participation of the stakeholders in water supply development and upkeep is one of the now generally acclaimed principles of the overall water sector.

The research revealed that gender relations and project procedures account for women having fewer opportunities than men to participate in discussions and decisions, in spite of their roles as users and managers of water, protectors of family health and educators of the new generation (Figure 9). Underlying these are the strategic constraints: no equitable division in rights, domestic and public roles, women's restrictions in autonomy over their own bodies, in access to and control over resources, independent choices in decision making, and rights to recognition and self-respect.

In attending meetings, women are hampered by lack of time, information and freedom of movement. The study revealed that women are often less informed about technical projects because project staff and village men consider this a male topic. In some villages, it is often difficult or impossible for women to attend predominantly male meetings, especially in male meeting places. Men heads of household represent the family and it is assumed that the women are informed and influenced by their husbands, even though the research reveals that much communication is gender-segregated, and so male family members will keep the information to themselves. Where women are able to attend meetings, they often do not speak out, and feel restrained by their lack of education and because of cultural barriers. Customary seating arrangements also limit their access to information.

At public meetings, the accepted role of a woman is often to listen to the men talk and women are not expected to express themselves. Women are also less familiar with the public sphere. They have little experience in public debates, and even women councilors have been found to express themselves less freely or frequently than men (Plumwood, 1992). Men travel more widely on business and attend political and religious meetings, while women's mobility is restricted largely to visits to relatives, the dispensary, market, or flour mill. However, even without expressing themselves directly, their attendance at meetings gives them access to project information as the first minor step to project involvement.

Meetings of local water councils and development committees are restricted mainly to men. The study has shown that the average number of women councilors is two out of 25 members. In the whole district, representation of women on approximately 21 community development committees is 4 percent. Absence of women in decision making organizations is also reported in other parts of the country.

Female members of councils or committees do not necessarily take part in water management decisions or act as representatives for the interests of all women (Shiva, 1989). Despite the fact that Buhera local authority is required to have one female member, the communication gap between men and women councilors and the community is very great. According to Zimbabwean Constitution, one third of the members elected on the local council must be women. The study revealed that often women did not know they were elected in local councils because the nomination committees sit without their knowledge. Women in the study area revealed that they are often we not informed of elections and were not given voting cards. Women on local water development councils can be obtained through the functional representation of all chairpersons of local organizations, including women's party branches, traditional women's organizations, and mothers' clubs. Local women are involved automatically through their clubs and organizations (Tinker, 1990).

Although such measures increase the chance of having several experienced women representatives, poor households are not always included, either because they have no organizations, or because their organizations are not recognized (Brown and Nooter, 1992). Also, representation at community level does not give women a say in decisions taken at a higher level. In Buhera, water development decisions, including the selection of villages for 
inclusion in the project and of well sites, are made by an all-male water project committee at district the District level. The following table 2 shows women representation in the study area.

Table 2 - Women in local water management structures

\begin{tabular}{|c|c|c|}
\hline Buhera District & $\begin{array}{l}\text { Women in Local Water Management } \\
\text { Institutions (\% of total) }\end{array}$ & $\begin{array}{l}\text { Women in Senior Position of Authority } \\
(\% \text { of total })\end{array}$ \\
\hline Chapwanya (Ward 1) & 21.9 & 7.2 \\
\hline Nerutanga (Ward 2) & 33.3 & 17 \\
\hline Maburutse (Ward 4) & 14 & 4.3 \\
\hline Gosho (Ward 5) & 22 & 9 \\
\hline Chigavakava (Ward 17) & 10.4 & 2 \\
\hline
\end{tabular}

Source: Survey, 2013.

The statistics in the study area shows that women are underrepresented in water management structures. These statistics are directly related to the quota systems for women in water management systems. The impact of these quotas can be seen when compared with other much lower percentages of women participation in water resource management in other districts.

The absence of women at local water management meetings and on governing bodies means that information and decision making is a men's affair, even on issues of which women have special knowledge and interest. This would be of less importance if they were consulted by the men. This has happened, for example in a water project in village 5 , where the local male leader had established a farmers' association with six appointed subcommissions, including one on home making. These were all consulted on the water project (Bhatia and others, 1993). In villages 5 and 6, members of a women's organization did not know that a water project was being implemented in their communities because the decisions were made by men dominated council. On the other hand, the local chief's council and the village development committee (both all male) were fully informed. Women in the study area further reported that they had not been informed in advance about the inconvenient location of the new wells, or that the council had not listened to their objections.

\section{BARRIERS TO GENDER PARITY IN WATER RESOURCES MANAGEMENT}

The research revealed the inequitable position that women are in when compared to men and this lack of parity creates major barrier to women's participation. In most cases women lives are constrained by obstacles such as culture and tradition (the view that women are superior to women), religion, lack of education and poverty.

The research revealed that patriarch is one of the major factors hindering gender parity in water resources management. A combination of patriarchy, conservation religious interpretations and cultural stereotypes has built a very strong psychological barrier among people in the study area, regarding women participation in water resources management. The hierarchical structure of communities in Buhera is another factor that contributes to the current state of affairs. Ultimately, an acceptance of women rights and possibly and unconscious fear for change have become a major challenge that has to be dealt with.

Water rights are often closely tied to land tenure arrangements and are usually transferred with land. Land rights in Buhera are passed from father and son. Thus, although women work on the land, they have no right to participate in institutions that make decisions regarding land use. Women in Buhera also lack skills relevant to participating in water governance partly because of their lower access to education and resulting in lower self confidence. Women are often less informed about technical water projects because stakeholders consider this a male topic. At public meetings, the accepted role of women is often to listen to men talk and is not expected to participate in public debate.

Social norms and attitudes in Buhera have eulogized women's role in private sphere and have limited their participation in the public sector. Diamond (1997) sees gender roles and dynamics within the household as being shaped by traditional gender paradigms that 
presumes that the most important contribution women can make is to family and society, as homemakers and mothers. While diamond puts this paradigm forward to explain their low rates of participation in the labour force, it can easily be applied to explaining low rates of women participation in water resources management. The research noted that the gender paradigm in the study area is primarily based on the following assumptions

- The centrality of the family, rather than the individual as the important unity of society, this emphasis is seen as justification for equivalent, rather than equal or rights;

- The assumption that the man is the sole breadwinner of the family; hence it is the man's prerogative to determine participation in water resource management;

- A 'community code of modest' under which family honor and dignity rest on the reputation of the woman this code imposes restrictions on interaction between men and women during water management meetings.

While women in the study area have acquired their full political rights as citizens, unless they acquire their full social and economic rights, their participation in water resource management will remain curtailed.

The patriarchal order which communities in Buhera share permeates women organizations and is an obstacle to society becoming a major force of change. The study

revealed that women organizations have not been credited with helping women's participation in water resources management. Rather, most women organizations have been criticized for adopting patron-client patterns of leadership, thus emulating the patriarchal patterns found in the society at large.

\section{RECOMMENDATION FOR SCALLING GENDER MAINSTREAMING IN WATER AND SANITATION IN BUHERA}

The research noted some of the factors that need to be addressed to implement a gender approach to water resources management in the study area. A focus on both men and women is crucial to the approach. Without urgent addressing of the following recommendations, efforts to achieve MDGs will remain elusive.

Equitable access to land rights and water for productive use: Equitable access to water for consumption and productive use can empower women to address the root causes of poverty and gender inequality. However lack of ownership to land is the underlying cause of women's limited access to water and a key reason for the greater poverty of female headed households in the study area. In Buhera, land ownership is a precondition for access to water and shockingly women hold title to less that 3 percent of the land. Moreover, even where women have a legal right, customs and patriarchy often prevent them from taking de facto control of land and water resources. Therefore, it is crucial to accord women recognition as land holders and contributors to the development process. Responding to the needs of poor households require a detailed understanding of men's and women's local knowledge systems, resource utilization and income generating opportunities.

Enhancing access to water: The research revealed that lack of access to water facilities and poor hygiene cause water-borne diseases such as diarrhea, cholera, typhoid and other parasitic infections. The social and environmental health costs of ignoring the need to address sanitation are too far great. A focus on gender differences is of particular importance with regard to water and sanitation initiatives, and gender balanced approaches should be encouraged in plans and structures for implementation.

Capacity development: Building capacity in water resources management means bringing together more resources, more people (both men and women) and more skills. Yet, when looking closely at capacity building in water supply and sanitation, it becomes clear that most of the training is aimed at water resources and water supply specialists. Very few programmes are aimed at expertise in social development, sanitation, or hygiene education that emphasize a gradual scaling down to those responsible for operation and maintenance of water supply and sanitation, who are primarily women. Targeting women for training and capacity building is critical to the sustainability of water management initiatives, particularly in 
technical and managerial roles to ensure their presence in the decision-making process (Sing and others, 2000).

Participation and equity in decision making: The research revealed that women are under-represented in the local water management structures, with careers and training in water management dominated by men. If water management is to be democratic and transparent (and presents the needs of the people) both men and women should have equal decision making responsibilities. A start has been made through the increase in the number of women serving as secretaries, but the empowerment of women as water managers must also be felt at the grassroots level. Affirmative action programmes in the water sector should be implemented at the local level to train women for water and sanitation related careers.

Protection of resource base (indigenous perspective): Indigenous people in Buhera possess traditional knowledge and skills concerning the sensing and location of water and protection of the source. Water sources on indigenous lands are often considered a sacred element, and indigenous women are the holders of 'water knowledge'. Their traditional land management skills provide the most effective method of water resource management in their settlement areas. The research noted that people in the study area are greatly affected by uncompensated and unsustainable loss of water to farming and other uses introduced from outside their communities. Measures should be put in place so that local communities can develop their capacities to achieve sustainable and equitable self-development.

Private sector participation, pricing and the right to water: an issue that has created much controversy in the study area is the involvement of the private sector in the provision of water services. Those who are opposed to privatization of water services are arguing that water is a fundamental right and not a commodity that can be bought and sold for profit. This argument is in sync with the November 2002 ruling (General Comment No. 15) of the United Nations Committee on Economic, Social and Cultural Rights that states that access to adequate amounts of clean water for personal and domestic use is a fundamental human right. Stakeholders who oppose this view further point to the recent evidence in the study area which shows that privatization of water points and access can have negative ramifications in terms of water distribution for the poor, who are unable to meet pay for adequate supplies. Simultaneously those in favor of private sector involvement such as nongovernmental organizations point out that water tariffs are required to improve water allocation and efficiency and encourage the resource conservation. Nonetheless, whether or not water has a price is not directly related to private sector involvement in water services. Partnership involving both public and private providers can be very effective in expanding services to a wider network of customers. As long as government retains oversight over water quality and ownership of the resource, private sector involvement can result in positive outcomes.

\section{CONCLUSIONS}

Gender - sensitive approaches to water resources management are desirable for the achieving efficiency, social equity and gender equality goals. The targets such as those in the MDGs relating to water are unlikely to be achieved unless gender perspectives are integrated into planning and implementation activities. Instrumental approaches to ensuring more reliable, sustainable and well-managed water supplies are essential to achieving access to water for all, and for ensuring the maintenance of water in the interest of local ecological balance and the needs of future generations. Nevertheless, social and economic targets (such as eliminating poverty, furthering empowerment of marginalized groups, supporting the resilience of the vulnerable and ensuring resources are appropriately managed by those who use them) will only be achieved by a wider focus on social and power relations. Adopting gender - sensitive approaches therefore means rethinking water development in a number of ways.

It is important to recognize the need for inter-sectoral cooperation. People's livelihoods are not divided into sub-sectors and imposing artificial boundaries on the management of water for different uses is unlikely to yield anticipated results. A gender-sensitive approach 
helps to overcome some of the artificial sub-sectoral divisions in water as it involves looking at women's and men's lives as a whole and how they are shaped through gender norms and practices. Gender relations also impact development institutions, which need to pay particular attention to the way that such relations impact on the functioning of their work, as well as on the water resources management at the local level.

The research revealed that frameworks for gender analysis of water resources management that encompass issues of social and gender relationships as well as infrastructural provision are required to track both collective and individual actions and recognize both the separateness, and interdependencies of women's and men's interests. Such an approach is unlikely to be achieved through the use of check-lists alone, and gender analysis cannot be achieved in a one-off event. Rather it requires a re-thinking of the way in which development accommodates diversity, complexity and change, while retaining overall goals of an equitable and dignified life for all as indicated in the MDGs.

\section{REFERENCES}

[1] ACC/ISGWR. (1992). The Dublin Statement and the report of the conference-Dublin international conference on water and environment: Development Issues For The $21^{\text {st }}$ Century. 26-31 January, 1992, Dublin (Eire).

[2] Agarwal, B. (1997). Environmental action, gender equity and women participation, Development and Change, 28 (1). 1 - 44

[3] Bhatia, R.; Cestti, R; Winpenny, J. (1993). Water resources policies and the urban poor: Innovative approaches and policy imperatives. Washington, D.C.: World Bank.

[4] Blank, H. G.; Mutero, C. M.; Murray-Rust, H. (2002). The changing face of irrigation in Kenya: Opportunities for anticipating change in eastern and southern Africa. Colombo: International Water Management Institute.

[5] Boserup, E. (1970). Women's role in economic development, New York: St Martin.

[6] Brown, E.; Nooter, R.. (1992). Successful small-scale irrigation in the Sahel, Washington, D.C.: World Bank.

[7] Brundlandt, G. (1987). Our common future. The world commission on environment and development, Oxford: Oxford University press.

[8] Cleaver, F., Jobes K. (1999). Donor policies and gender in the water and sanitation sector, National Resources Forum 20 (1): 111-16

[9] Cleaver, F.; Elson, D. (1995). Women and Water Resources: Continued Marginalization and New Policies, London:International Institute for Environment and Development (IIED.

[10] Cleaver, F. (1998). Incentives and informal institutions: Gender and the management of water, Agriculture and Human Values, 12 (1): 123120

[11] Cornish, G. A.; Mensah, E.; Ghesquiere, P. (1999). Water quality and peri-urban irrigation: An assessment of surface water quality for irrigation and its implications for human health in the peri-urban zone of Kumasi, Ghana. Wallingford: Department for International Development (DFID)

[12] Commonwealth Secretariat, (1996). Women and Natural Resource Management: The Overview of a Pan-Commonwealth Training Module, London,

[13] Danish Agency for Development Assistance (1999). Gender and Water Supply and Sanitation: Guiding Questions Working Paper, Ministry of Foreign Affairs, Danida

[14] Diamond, N. (1997). A Working Session on Communities, Institutions and Policies: Moving from Environmental Research to Results, WIDTECH (funded by the Office of Women in Development, Bureau for Global Programmes, Field Support and Research, U.S. Agency for International Development), Washington, D.C.

[15] Espejo, N. (1993). Gender and the Management of Drinking Water Supply in LowIncome Urban Communities in Latin America, Netherlands: International Water and Sanitation Centre (IRC).

[16] Gleick P.H. (2006). The world's water 2006 - 2007: The biennial report on fresh water resources. Washington DC: Island 
[17] Green, C., Baden, S. (1995). Integrated water resources management: A gender perspective. IDS Bull. 26 (1). $92-100$

[18] Food and Agriculture Organization (FAO) (1995). Irrigation in Africa in figures. Report No. 7. Italy.

[19] FAO. (1998). Wetland characterization and classification for sustainable agricultural development. Sub- Regional Office for East and Southern Africa (SAFR). Harare.

[20] Jackson, C. (1998). Gender, irrigation and environment: Arguing for agency. Agriculture and Human Values 15 (1). 313 - 324.

[21] Hatibu, N. (2003). Contribution of rainwater harvesting to improving incomes and food security in Eastern and Southern Africa. Paper presented at the Water and Food Session in the Africa Days of the Third World Water Forum, Kyoto. March 16-22.

[22] Meinzen-Dick, R; M. Rosegrant. (1997). Managing water supply and demand in southern Africa. In L. Haddad, Achieving food security in southern Africa. Washington, D.C.: International Food Policy Research Institute.

[23] Merchant, C. (1996). Earth care: women and the environment, New York: Routledge Michael, B. P. (1998) The Role of Women in Water Resources Management: The Tanzania Case.

[24] International Journal of Water Resources Development, 14 (4): 123134.

[25] Plumwood, V. (1992). Beyond the dualistic assumptions of women, men, and nature, Ecologist 22 (1): 8-13.

[26] Postel, S. 1992. Last oasis: Facing water scarcity. New York: W.W. Norton and Company.

[27] Shiva, V. (1989). Staying Alive: women, technology and development, London: zed books.

[28] Singh, N., Jacks, G., Bhattacharya, P., Gustafsson, J. E. (2000). Gender and water management: Some Policy reflections. Water policy 8(1):183 - 2000.

[29] Tinker, I. (1990). Persistent Inequalities: Women and World Development, New York: Oxford University Press.

[30] Visscher, J.T; Werff, K. (1995). Towards Sustainable Water Supply: Eight Years of Experiences from Guinea-Bissau, The Hague, IRC International Water and Sanitation Centre.

[31] World Bank (1998). World Bank Report on Water Development. Washington DC, The World Bank.

[32] United Nations (1995a). Beijing declaration and platform for action. New York. United Nations Publications.

[33] United Nations (1995b). The world's women. Trends and statistics, United Nations: New York Publications.

[34] UNICEF. (1994). Clean water and environment: women children at particular risk. , New York: UNICEF.

[35] United Nations (1992). Agenda 21. Organisation of United Nations, New York. 